\title{
Contribution of academic tutoring for the teaching-learning process in Nursing undergraduate studies
}

\author{
Contribuição da monitoria acadêmica para o processo ensino-aprendizagem na graduação em enfermagem
}

Contribución de la tutoría académica para el proceso enseñanza-aprendizaje en la graduación en enfermería

\section{Erlon Gabriel Rego de Andrade', Ivaneide Leal Ataíde Rodrigues', Laura Maria Vidal Nogueira', Dilma Fagundes de Souza'}

\author{
' Universidade do Estado do Pará, Magalhães Barata School of Nursing. Belém, Pará, Brazil.
}

How to cite this article:

Andrade EGR, Rodrigues ILA, Nogueira LMV, Souza DF. Contribution of academic tutoring for the teaching-learning process in Nursing undergraduate studies. Rev Bras Enferm [Internet]. 2018;71(Suppl 4):1596-603.

[Thematic Issue: Education and teaching in Nursing] DOI: http://dx.doi.org/10.1590/0034-7167-2017-0736

Submission: 11-28-2017 Approval: 01-24-2018

\begin{abstract}
Objective: to analyze the perceptions of professors and students on academic tutoring. Method: descriptive study with a qualitative approach, carried out at the Magalhães Barata School of Nursing, State University of Pará, Brazil. Twenty-seven professors and 32 students participated in the study. Data were collected through semi-structured and individual interviews, using different scripts for professors and students. For analysis, the technique of content analysis was used. Results: we defined three thematic categories: academic tutoring as a tool for strengthening teaching-learning; academic tutoring as a possibility of intellectual and social transformation; and reflections of academic tutoring in nurses' training. Final considerations: the teaching-learning process is referred to as a process in which there must be dialogue, and in which professors, students, and tutors learn with each other, breaking the traditional paradigms of unilateral and vertical transfer of content. Academic tutoring stands out as promoter and strengthener of this process.
\end{abstract}

Descriptors: Tutoring; Higher Education; Nursing; Education in Nursing; Nursing Students.

\section{RESUMO}

Objetivo: analisar a percepção de docentes e discentes sobre a monitoria acadêmica. Método: estudo descritivo, com abordagem qualitativa, realizado na Escola de Enfermagem Magalhães Barata, da Universidade do Estado do Pará. Participaram 27 docentes e 32 discentes. Os dados foram obtidos por meio de entrevistas semiestruturadas e individuais, utilizando-se roteiros diferentes para docentes e discentes. Para análise, utilizou-se a técnica de análise de conteúdo. Resultados: definiu-se três categorias temáticas: a monitoria acadêmica como ferramenta de fortalecimento do ensino-aprendizagem; a monitoria acadêmica como possibilidade de transformação social e intelectual e os reflexos da monitoria acadêmica na formação do enfermeiro. Considerações finais: o ensino-aprendizagem é referido como um processo no qual deve haver diálogo, e onde docentes, discentes e monitores aprendem mutuamente, rompendo os paradigmas tradicionais de repasse unilateral e vertical de conteúdos. A monitoria acadêmica destaca-se como propulsora e fortalecedora de tal processo.

Descritores: Monitoria; Educação Superior; Enfermagem; Educação em Enfermagem; Estudantes de Enfermagem.

\section{RESUMEN}

Objetivo: analizar la percepción de docentes y discentes sobre la tutoría académica. Método: estudio descriptivo, con abordaje cualitativo, realizado en la Escuela de Enfermería Magalhães Barata, de la Universidad del Estado de Pará. Participaron 27 docentes y 32 estudiantes. Se obtuvieron los datos por medio de entrevistas semiestructuradas e individuales, utilizando guías diferentes para docentes y discentes. Para el análisis, se utilizó la técnica de análisis de contenido. Resultados: se definieron tres categorías temáticas: la tutoría académica como herramienta de fortalecimiento de la enseñanza-aprendizaje; la tutoría académica como posibilidad de transformación social e intelectual y los reflejos de la tutoría académica en la formación del enfermero. Consideraciones finales: la enseñanza-aprendizaje se refiere como un proceso en el que debe haber diálogo, y 
donde docentes, discentes y tutores aprenden mutuamente, rompiendo los paradigmas tradicionales de repaso unilateral y vertical de contenidos. La tutoría académica se destaca como propulsora y fortalecedora del proceso.

Descriptores: Tutoría; Educación Superior; Enfermería; Educación en Enfermería; Estudiantes de Enfermería.

\section{INTRODUCTION}

Nursing performance requires technical and scientific reasoning, based on ethical and humanistic principles, so that the nurse's social practice and policy is resolutive and transformative $^{(1-2)}$. Higher education contributes decisively to the sharing of knowledge and experiences, developing dialogical strategies of knowledge-building between professors and students, making both feel responsible for the teaching-learning process and developing skills for a shared construction ${ }^{(3)}$.

In this perspective, higher education may enable policies for ethical and committed training, preparing professionals who shall act in mobilizing transformations and fulfilling their social and political role as citizens. To this end, structure and resources are necessary to meet the needs of the learner, reinforcing knowledge, noting aspirations and expectations, and clearing out uncertainties and ambiguities in the teaching-learning pro$\operatorname{cess}^{(3-5)}$. Thus, higher education institutions should offer training in nursing taking into consideration the emergencies of the globalized world, its work organization, manners and conditions of life, and health conditions of different population groups ${ }^{(3,6)}$.

In the context of this training, academic tutoring is specially relevant, understood here as an educational support tool through which the student-tutor and the supported student have opportunity to deepen knowledge, strengthen theoretical and practical skills, and clarify doubts, remedying the weaknesses inherent to an area of knowledge. Favoring the integration between theory and practice, tutoring creates a fertile space for questions and for review of contents, techniques, and procedures, in line with the pedagogic project of the undergraduate program ${ }^{(1,7)}$.

Understanding that human and academic development actions are paramount to higher education, Brazilian Law No. 5,540/1968 regulated academic tutoring, setting rules for the organization and functioning of higher education and its connection with High School ${ }^{(8)}$. It was reiterated later by Law No. 9,394/1996, which established the guidelines and bases for national education ${ }^{(9)}$, regarding the use of students for teaching and research activities given their performance and technical-didactic skills $s^{(10)}$.

In the context of the State University of Pará (UEPA), Resolution No. 2,808/2015 of the University Superior Council (Consun), regulates the tutoring program by defining its nature as to promote learning spaces, awaken and develop interest by teaching activities, and improve teaching ${ }^{(11)}$.

The interest to investigate the theme arose in the exercise of voluntary tutoring of the curricular component "Parasitology", within the Nursing undergraduate program of the "Magalhães Barata" School of Nursing (EEMB). The subject is taught in first year/block II and integrates the thematic axis "Epidemiological Determinants of the Health-Disease Process"(12). Following the regular classes, it was possible to notice that the contributions of the tutor emerged with potential and relevance in the training of students who, along with the professor, shared collective experiences in the construction of the teaching-learning process.

Despite the importance of the tutoring program, there are few studies published on the theme within the Brazilian scientific production. This was verified during a state of the art survey, searching the Virtual Health Library (VHL), considering the period from 2011 to 2015 and studies conducted in Brazil.

\section{OBJECTIVE}

To analyze the perceptions of professors and students on academic tutoring.

\section{METHOD}

\section{Ethical aspects}

The research was developed in accordance with Resolution CNS No. 466/2012. The project was approved by the Research Ethics Committee of the School of Nursing, State University of Pará. The participants were identified with an alphanumeric code, using the letter $\mathrm{P}$ for professors, and A (of academic) for students, followed by the serial number of the interviews.

\section{Type of study and scenario}

We opted for a descriptive study with a qualitative approach, in which the researcher seeks to reduce the distances between the theory and the data found by analyzing the design of phenomena by their description and interpretation ${ }^{(13)}$. The research was carried out on EEMB/UEPA, located in Belém, state of Pará, Brazil, with students and professors of the undergraduate program in Nursing. The course lasts five years, divided into five series and ten half-yearly blocks (each series consists of two blocks), organized into 15 thematic axes. The professors are nurses or professionals from other areas, being specialists, masters, and doctors, hired and effective ${ }^{(12)}$.

\section{Data source}

The research included 59 participants, 27 professors and 32 students, representing $93.1 \%$ of professors and $94.1 \%$ of students regarding the envisaged number of 29 and 34, respectively, expressing a participation percentage of $93.6 \%(59 / 63)$. The participants were selected for being direct beneficiaries of the actions developed by student-tutors and co-participants of the teaching-learning process. Four participants were excluded, two teachers and two students, due to the impossibility of agreeing on appropriate days and times for interviews.

Effective or substitute professors of subjects that counted with the participation of tutors for at least two semesters were included. The students selected were those registered in the 
second half of 2016, in morning or afternoon periods, currently on the $5^{\text {th }}$ year. This cut is justified because these students had already been through several experiences in previous subjects, either as tutors and/or assisted students.

\section{Data collection, organization, and analysis}

Individual semi-structured interviews were carried out with the aid of scripts prepared by the researchers, one for teachers and another for students, whose questions explored the teaching-learning process and aspects related to the contributions and benefits of academic tutoring on the nurse's training. The interviews occurred mostly on campus.

For data analysis, content analysis ${ }^{(14)}$ was employed, considering its three stages. Thus, the statements were first analyzed and classified regarding the recording units corresponding to each question and, later, by respondent, to identify the themes that occurred more often. Finally, the overall analysis of the participants' answers for the set of questions was carried out. This analysis allowed the identification of 59 recording units, 27 of professors and 32 of students, which were predominantly distributed in eight themes, according to occurrence and co-occurrence.

Similar themes were organized into thematic categories according to the aspects identified that complied with the study's objectives. The categories were: "academic tutoring as a tool for strengthening teaching-learning"; "academic tutoring as a possibility of intellectual and social transformation"; and "reflections of academic tutoring in nurses' training".

\section{RESULTS}

Among the participants, the female sex predominated for both professors and students, with $74.1 \%$ (20/27) and $78.1 \%$ (25/32), respectively. The professors were aged from 30 to 68 years, and the age group of 60 to 64 years old prevailed, with $25.9 \%$ (7/27). Among students, age varied from 21 to 33 years, with the range from 21 to 25 years prevailing, with $68.8 \%$ $(22 / 32)$. Regarding the area of training of professors, Nursing prevailed, with $77.8 \%(21 / 27)$, followed by Biomedicine $(7.4 \%$, $2 / 27$ ), and Biological Sciences $(7.4 \%, 2 / 27)$. As for the level of training of teachers, masters predominated, with $48.2 \%(13 / 27)$, and PhDs, with $40.7 \%(11 / 27) ; 88.9 \%$ (24/27) were effective professors. Time of teaching at the Institute ranged from 3 to 36 years, prevailing a period of 27 years, with $14.8 \%(4 / 27)$.

As for tutoring, we identified that $34.4 \%(11 / 32)$ of students had already experienced it, and $63.6 \%$ (7/11) were effectively experiencing it at the time of the interview. We found that $72.7 \%(8 / 11)$ acted as tutors in only one subject, and $45.4 \%$ $(5 / 11)$ were tutors for a period of one semester.

\section{Category I: Academic tutoring as a tool for strengthening the teaching-learning process}

In this category, the participants' perceptions as to the meaning of the teaching-learning process and the idea of how academic tutoring can foster its development in the context of higher education are addressed.

We found that the teaching-learning process is understood by professors and students as an instrument that promotes knowledge and experience exchange, as well as mutual learning among participants of a scenario in which different human relationships occur. The process is represented as complex, dynamic, continuous, and dialogic:

For me, this process is complete, dynamic, and interactive, it is an exchange [...]. (P13)

The teaching-learning process is a binomial, teach and learn. It is something that happens by doing a process of exchanging experiences, learning from both sides. So, when you teach [...], understanding that who learns has something to teach, you also learn. (P26)

It is something dynamic, [...] a gradual and continuous process. It is a constant exchange of knowledge, exchange of livings, of experience. (A2)

Teaching and learning, in my knowledge, would be the exchange of knowledges between individuals [...]. (A12)

The perception of the teaching-learning process as an inherent process in formal education and, in this sense, consolidated in the relations established between professors and students prevailed:

It is a dynamic process that needs to be participatory, in which both the professor and the students learn continuously at the time of the theory lesson, at the time of the practical lesson. (P22)

It is the process that happens as much in the classroom as in the practice field, it is that exchange between students and professors because I believe that the professor can learn from the student as much as the student learns from the professor. (A31)

Academic tutoring is recognized, by professors and students, as a tool for facilitating the achievement of an effective teachinglearning process, both for the one who performs the role of tutor, overseen by an advisor professor, and the assisted students, so that their knowledge and practices are strengthened:

The tutor is the one who aids the training of the assisted students and who learns with the assisted students and the professor. (P13)

[...] academic tutoring is an educational and teaching-learning process, in which the tutor (in a relationship between the subject, the facilitator of learning, and the student) can find himself, see himself, and add to his life and achievements this process of teaching and learning. (P20)

Tutors, in that subject they understand better, will be able to share, help the assisted students, who are studying that for the first time [...]. (A14)

Academic tutoring is an opportunity that is given to the student to help with the teaching and learning along with a supervisor, [...] it collaborates not only with the student's teaching-learning, with the class you are part of, but also with the tutor himself. (A17) 
The relationships developed between tutors and supervisor professors, considering that the tutor helps this professor in theoretical and practical activities, also gained prominence. This aspect was mentioned as beneficial to the success of the teaching-learning process, in particular for the assisted students, also denoting trust in the work of the tutor by the professor:

It is a person [talking about the tutor] who gives me the support I need, because, in the current situation, I have a number of students beyond my attention capacity, especially in practical lessons. [...] I must have this relationship of trust with him, because he is going to give me this support. (P23)

When you are a tutor, you assist the professor in that part, you assist in practical lessons [...]. (A13)

In the dynamics of relationships between tutor and assisted students, tutoring is, more than a process established in the context of higher education and with well-defined academic purposes, a meeting point between apprentices, who identify themselves as peers, under the understanding that the condition of being students make them equals, despite the tutor being one or more semesters ahead of assisted students.

This idea emphasizes tutoring as a process that fosters learning, considering that the students, relying on the tutor, find a fertile space to the clarification of doubts and consequent strengthening of skills, potentializing their knowledge with less fear and more accessibly, regarding the maintenance of contact, closer and more adapted language to the reality of the student, and the symmetries of the academic experiences. This differs from the relationship between students and professors, which sometimes is represented by fear, shyness, and verticality to the apprentice:

Often, a student feels more comfortable with another student, and the languages are better adapted and better understood from student to student. (P3)

The exchange of experiences among peers is much easier, I think, than between the professor and the students. [...] The tutor is equal to their peers. Therefore, we have the same language, we know where I, as a student, had my difficulties in specific subjects. (P24)

The tutors I had made my life easier, because we know that, before a professor, people feel more insecure. [...] We will have more freedom to ask, because we know they are students and they went through that experience that we are now going through. (A15)

That trust that the student has on the tutor, for also being an undergraduate student, [...] we have more freedom, more autonomy to ask, to question, and we end up having more advantages in learning. (A26)

Often, given the fear students have of approaching professors to enhance the educational process, the tutor is seen as a key element of dialogue and mediation between the professor and the class, socializing with the professor the limitations of students, as highlighted by both:
Sometimes, some teachers do not get what the students want, and the tutor, for being a student, gets it, he understands better and brings these problems, and we, together, try a solution. (P13)

[...] give a feedback of the class to the professor, because sometimes students feel more comfortable to talk about certain difficulties with the tutor, [...] thus, we facilitate for the professor what points should be addressed to better elucidate better to the students the topics they have difficulties. (A22)

\section{Category II: Academic tutoring as possibility of social and intellectual transformation}

Here, we discuss the perceptions of how tutoring can enable transformation processes in the cognitive-intellectual and social levels, as well as the improvement of the students' resume, with the possibility of entry in graduate school, approval in civil service examinations, and rise to a teaching career.

As for the the cognitive-intellectual and social transformations, professors and students expressed that the pursuit of knowledge and the mobilization of the sense of responsibility for the training of another student are relevantly encouraged.

Regarding the pursuit of knowledge, the respondents understood that, for being someone who has the task of sharing technical knowledge and experiences related to his/her area of expertise in the class, the tutor needs to be constantly updated to clarify questions and present good performance during his/ her assistance:

He [the tutor] will study more, will commit to the contents of that subject. (P1)

The tutor is always studying, you have to train, because he is going to be some sort of reference to other students, to your colleagues. (A21)

Concerning the responsibility for another student's training, it was reported that tutors, from the moment they understand their role, transpose the vision of being responsible only for their own training, beginning to occupy a prominent position when exercising a privileged function, full of possibilities for the education of the assisted student as well as of the tutor. Their commitment is required with this occupation, which includes, among other responsibilities, the observance of timetables and demonstration of care for the learning of another:

You assist your friend, but now you have other responsibilities, you are a student-tutor. (P6)

He [tutor] has this opportunity of taking the responsibilities, of being in the classroom on time, and when there are practical lessons, he needs to move to locations. I think that helps develop maturity [...]. (A6)

The improvement of the academic curriculum as a result of the experience with tutoring was pointed out. Therefore, the possibilities for entry into graduate degrees are broadened, especially residences and master's and PhDs degrees, as well as approval in civil service examinations: 
He [the tutor] also incorporates this into his resume, because, when he graduates, he goes to the labor market. If he takes a resume, especially if he is going to do a masters, or participate in a selection process for graduate school, this is a bonus. (P18)

[...] it enriches the resume, because it has been one of the criteria of examinations and residencies, you gain extra points for being a tutor. (A19)

As for the possibility of teaching practice, we identified that the reports are positive and indicate that this experience enables rise to higher education teaching, given the opportunities to be inserted in the pedagogical aspects that directly permeate education:

It is an opportunity to get to know, to awaken, to stimulate the teaching practice in the future, especially higher education in Nursing. (P10)

Tutoring is an opportunity for the student to develop his skills regarding teaching, thinking about being a professor. (A8)

\section{Category III: Reflections of academic tutoring in the nurse's training}

In this category, we present the perceptions that reflect the importance of tutoring for the future nurse's training and the representations inherent to the tutor's co-participation in the operational development of subjects that make up the curriculum of the pedagogic project of the undergraduate program in nursing of UEPA.

As for importance, we identified the overall understanding that the tutoring program contributes greatly to the promotion of successful experiences for the student to understand the purposes of the profession and the various areas that are specific to Nursing, which must be carried out expertly by this professional when entering the labor market.

It is equally important for the student to understand the essence of basic knowledge areas, mainly focused on the first semesters, considering that they provide theoretical and practical subsidies for a competent and safe performance of care:

The tutor speaks of his experience from other subjects, which ends up adding to the subject he is tutoring [...]. For example, discussions in the classroom, in which the tutor had a knowledge of Basic Health Units as we were experiencing a reality of the hospital area, and he brought that experience and it was excellent. (P2)

As my background is not Nursing, when I have a tutor from the area of Nursing, he contributes to my understanding and passes that on to my students. I improved a lot from when I first started teaching, because I was demanding certain things that were not necessary for nurses. (P5)

I was tutor of Anatomy. Sometimes, the students questioned why they were studying a particular subject, or why did they had to study the skin, human senses, cardiology [...]. I always insisted on how there will be situations, depending on the career that they follow, or even during the undergraduate course, in which they will experience certain clinical conditions. (A27)
She [tutor] will expand your horizons, you will understand better the practice, the theory, anyway, the subject in question. (A32)

Regarding the contributions to the operational development of the subject, most participants reported that the tutor acts facilitating the success of the specific processes of each area of knowledge, either to make a practical lesson possible, an extraclass experience, a different experience from the regular ones in a subject, or even to facilitate learning in the classroom and laboratory, participating in the direction of the lessons along with the advisor professor.

Our field trips have a very large logistics, and the tutor helps from the contact with the boatman, reinforcing with the class the meeting place to take the boat and go to Combú [island] or to the Quilombo Abacatal. (P3)

When I taught Community Nursing, I would always do group works, text readings, and group discussions, [...] the tutor helped me a lot in class observation, understanding and observing participation, the quality of the discussions. He participated, and we discussed. (P26)

I understand that, for example, in Physical Examination Techniques, the tutor was as relevant as the professor, for our technical training. He was an engaged tutor. (A3)

In Physical Examination Techniques, there is always a tutor to keep an eye on us, even when the professor cannot observe all students or fails to meet any needs. (A20)

\section{DISCUSSION}

In the participants' perception, the predominant understanding is that the teaching-learning process is configured as dynamic, implying relationships and knowledge sharing and, therefore, unable to fully achieved if operated under the perspective of unidirectionality and verticalization of knowledge, in which someone who holds the knowledge transfers it to someone who does not.

To be fulfilled, the teaching-learning process requires dialogue and experience built by the active participation of individuals, considering that everyone has something to teach and learn, as they are equipped with knowledge that comes from their life experiences, which leverage mutual learning and collective and participatory construction of knowledge $\mathrm{e}^{(15-17)}$.

Even in a limited reality, this denotes the breaking of the paradigms that prevailed for a long time in the context of education, particularly in basic and higher education, and that, although still currently rooted to teaching methods, have been progressively deconstructed by insertion of emancipatory practices of cognitive and intellectual development, in which apprentices are instigated to be in the center of their own knowledge ${ }^{(5,18-19)}$.

In this sense, academic tutoring is a strategy to strengthen the teaching-learning process in higher education - the perspective that was mostly expressed by participants. This contribution is materialized in the development of theoretical and practical activities, in the classroom, laboratory, and fields of practice, providing the basis for the technical-scientific and problematizing improvement of tutors and the assisted students. This 
is reflected in the satisfactory learning of the assisted student, therefore, strengthening the pedagogical project of the undergraduate course $\mathrm{e}^{(1,7,20-21)}$.

An important aspect of tutoring is the interaction between the professor and the student-tutor, enabling the academic development of tutors and aid to professors ${ }^{(22)}$, always in line with their attributions, listed in chapter IV of Resolution No. 2,808/2015, CONSUN/UEPA ${ }^{(11)}$. As reported by the participants, the tutor is a key element in the teaching-learning process, which allow us to infer that learning would not flow with the same success without his/her participation.

This fact is corroborated by a study at the Federal University of Rio de Janeiro, with eleven former tutors from the Nursing undergraduate course, students from the $7^{\text {th }}$ to $9^{\text {th }}$ semesters, when stating that the program was implemented in the institution for the purpose of, among others, provide a more significant bond between professors and students facilitating conditions for students' assistance and implementation of educational tasks, such as practical activities. The students, when talking about the activities they developed, specially cited their contributions in the preparation, coordination, and management of works, exercises, directed studies, and practical and theoretical lessons ${ }^{(10)}$.

In the relationship between tutor and assisted students, the prevalent understanding that learning gains greater possibilities of being successful results from the symmetric identity condition that determines the approximation between tutors and students, and makes learning a tangible process, close to the reality of students, who find support in the tutor not only to overcome weaknesses, but, above all, to have their potential awakened ${ }^{(1,10,20,22)}$.

Since part of the experiences of the assisted students converges with those of the tutor concerning the eagerness to achieve successful experiences, academic and personal achievements began to have different connotations, as something more clearly feasible, despite the difficulties inherent to the student and life trajectory ${ }^{(10)}$. In addition, the tutor is assigned with a mediator role between the professor and the class, enabling the dynamics of this relationship ${ }^{(21)}$.

Here the importance of the tutor not only as a professional in training, but as a person, endowed with sensitivity and humanity, stands out. A tutor's attribution of going beyond the walls of the university and offering human support, with affection and empathy, is essential for a process of active and reflective training ${ }^{(15-16)}$.

The feeling of responsibility for having to guide the peer through the teaching-learning trajectory, clearing out uncertainties and strengthening knowledge and practices, triggers the tutors' self-reflection and critics, considering the need to improve and be a protagonist in search of knowledge, taking ownership of new readings and other sources, since the function they now perform demands that attitude, as mentioned in other studies ${ }^{(10,20)}$.

In this perspective, we point out the privileged position of educators in the guidance of the tutors that accompanies them, respecting their particularities and noting aspirations and expectations, so that they guide the tutors in order to develop skills in a dialogical and shared way, with co-responsibilities, multilateralism, and horizontality, visualizing the apprentices' potential $^{(3,5,17)}$ so that this tutor shall also act like this toward the assisted class.
In this study, we noticed that the desire to become a professor was an important factor for the search for tutoring, and that sometimes this desire results from the students' performance when facing processes that gradually involve them in questions related to teaching, of pedagogical-administrative nature or related to teaching, research, and extension ${ }^{(10,23,25)}$. Therefore, we infer that, for the respondents, the stimulus to higher education teaching is among the most important goals of tutoring.

Improvement of the resume was another aspect mentioned as part of the possibilities of social and intellectual transformation, since the experience will be put in the resume, which drives the students in their personal, academic, and future professional achievements, when entering graduate programs, being approved in civil service examination, or getting a job ${ }^{(10,24-25)}$.

Tutoring presents itself as a promoter of the successes of the training processes, in line with the basic areas of biological and health sciences, in addition to the specific area of Nursing practice, as expressed by some participants.

The tutor's performance, cooperating with the professor in the management of educational activities and being especially close to the students, has a direct impact on the assimilation and internalization, by the assisted students, of the purposes of each area to their academic and professional training ${ }^{(1,10,20)}$. Therefore, it is understood that the program directs, in a more accessible way, the understanding of nurses' performance in its different spectra: care, management of human resources, management of health and nursing services, teaching and research, or the political participation and social control they can exercise ${ }^{(26-29)}$.

Facing the possibilities and specificities of Nursing, which sometimes differ from those expected by freshmen students, it is important to highlight the role of the tutor in facilitating the understanding of basic curriculum components of biological, health, human, and social sciences, especially in the first semesters, a period in which the feeling of not belonging and, sometimes, of demotivation is recurring among students, due to immaturity and lack of academic perception as to the practical application of such knowledge in Nursing and everyday life.

The tutor enables the understanding of these subjects with practical examples, reiterating the need for integration between the different knowledge for the interdisciplinary performance of nurses, motivating the students to study hard. The purpose is to train professionals who are committed, critical-reflective, with general and humanistic skills, willing to learn how to learn and who are able to discuss different realities, meeting the health needs of the individual, families, and the community in the biopsychosocial perspective, in line with the National Curriculum Guidelines of the Undergraduate Program in Nursing ${ }^{(30-32)}$.

\section{Study limitations}

Even though we had an expressive number of participants, we understand that the perceptions and inferences discussed here cannot be generalized, given the influence of sociocultural, economical, political, academic, scientific, organizational, and operational aspects specific to the studied region. But, certainly, our data can contribute to reflections on similar realities - in other public universities, for example. 


\section{Contributions to the field of Nursing}

We understand that the study brings important contributions to the reflection on the effectiveness of academic tutoring in the teaching-learning process and its relevance in the context of higher education. The study may also contribute with advances in research on the theme and, potentially, to the improvement of the undergraduate course in Nursing, impacting the training of better prepared professionals to meet the health needs of different human groups.

\section{FINAL CONSIDERATIONS}

This study described the perceptions of professors and students regarding the contributions of academic tutoring for the teaching-learning process in Nursing training. The teachinglearning process is described as a process in which there must be dialogue and exchange, in which professors and students learn while teaching, breaking the traditional paradigms of unilateral and vertical transfer of content. In this context, academic tutoring is highlighted as a promoter and strengthener of this process.

Another highlighted aspect is the idea that tutoring is very much valued in the academic context. Tutors are seen as model students, given the ethical and respectful posture they should assume. They are also expected to have academic maturity and exemplary attitudes in searching and sharing knowledge, which can inspire those under their guidance to maintain or adopt a similar posture. The tutor is someone who circulates among professors, and, either if they are from the same area or not, they recognize the tutor as an essential actor to the undergraduate course, as the "right-hand" of the professor.
Appreciation is also expressed by the assisted students, not only for seeing the tutor as a reference, but for counting on him/her for effective learning and complicity. Tutors, being students, understand the needs of their peers and sometimes take sides, claiming causes of mutual interest. This makes the bonds between tutor and assisted student significant, and the relationship, once restricted to the university, transcends to friendship, greatly strengthening these bonds.

On the development of Nursing, there is the perception that tutoring contributes to the renewal of the specific and profession-related knowledges and, considering knowledge to be dynamic, it is continuously transformed and therefore cannot stagnate. The process aids in the identification and sharing with health and nursing teams of knowledges that foster the qualified performance of care, corroborating to the nurses' role as educator during training.

Tutoring was also recognized as a strengthening tool of the pedagogic project potential, by offering tutors the opportunity to participate in follow-up meetings and assessment forums, in which they can share the students' perceptions about the strengths and weaknesses of the current project and contribute with suggestions, taking into consideration the tutors' experience on both sides of the process, as students and as tutor.

From the results of this study, we reiterate the need for greater visibility of the theme by the academic community, considering its relevance despite the lack of national studies dedicated to unveiling the teaching-learning process and the relationships that happen through the implementation of the tutoring program, particularly in the training of nurses, with its implications for professional performance.

\section{REFERENCES}

1. Carvalho IS, Lima Neto AV, Segundo FCF, Carvalho GRP, Nunes VMA. Monitoria em semiologia e semiotécnica para a enfermagem: um relato de experiência. Rev Enferm UFSM [Internet]. 2012[cited 2015 Jun 27];2(2):464-71. Available from: https://periodicos. ufsm.br/reufsm/article/view/3212/3775

2. Zoboli ELCP, Schveitzer MC. Nursing values as social practice: a qualitative meta-synthesis. Rev Latino-Am Enfermagem [Internet]. 2013[cited 2016 May 16];21(3):695-703. Available from: http://www.scielo.br/pdf/rlae/v21n3/0104-1169-rlae-21-03-0695.pdf

3. Backes DS, Grando MK, Gracioli MSA, Pereira AD, Colomé JS, Gehlen MH. Vivência teórico-prática inovadora no ensino de enfermagem. Esc Anna Nery Rev Enferm[Internet]. 2012[cited 2016 Feb 11];16(3):597-602. Available from: http://www.scielo.br/ pdf/ean/v16n3/24.pdf

4. Sobral FR, Campos CJG. The use of active methodology in nursing care and teaching in national productions: an integrative review. Rev Esc Enferm USP [Internet]. 2012 [cited 2016 Aug 16];46(1):202-11. Available from: http://www.scielo.br/pdf/reeusp/v46n1/ en v46n1a28.pdf

5. Souza CS, Iglesias AG, Pazin-Filho A. Estratégias inovadoras para métodos de ensino tradicionais: aspectos gerais. Med[Internet]. 2014 [cited 2016 Aug 16];47(3):284-92. Available from: http://www.revistas.usp.br/rmrp/article/view/86617/89547

6. Canever BP, Prado ML, Backes VMS, Gomes DC. Produção do conhecimento acerca da formação do enfermeiro na América Latina. Rev Gaúcha Enferm [Internet]. 2012 [cited 2016 Aug 16];33(4):211-20. Available from: http://www.scielo.br/pdf/rgenf/v33n4/26.pdf

7. Fernandes NC, Cunha RR, Brandão AF, Cunha LL, Barbosa PD, Silva CO, et al. Academic mentoring and care for a person with a stoma: experience report. Rev Min Enferm [Internet]. 2015[cited 2016 Aug 16];19(2):242-5. Available from: http://www.reme. org.br/artigo/detalhes/1018

8. Brasil. Câmara dos Deputados. Centro de Documentação e Informação. Lei no 5.540, de 28 de novembro de 1968. Fixa normas de organização e funcionamento do ensino superior e sua articulação com a escola média, e dá outras providências[Internet]. 1968[cited 2016 Aug 16]. Available from: http://www2.camara.leg.br/legin/fed/lei/1960-1969/lei-5540-28-novembro-1968-359201normaatualizada-pl.pdf 
9. Brasil. Presidência da República. Lei no 9.394, de 20 de dezembro de 1996. Estabelece as diretrizes e bases da educação nacional. [Internet]. 1996 [cited 2016 Mar 27]. 32 p. Available from: http://portal.mec.gov.br/seed/arquivos/pdf/tvescola/leis/lein9394.pdf

10. Abreu TO, Spindola T, Pimentel RAR, Xavier ML, Clos AC, Barros AS. A monitoria acadêmica na percepção dos graduandos de enfermagem. Rev Enferm UERJ [Internet]. 2014[cited 2016 Aug 16];22(4):507-12. Available from: http://www.facenf.uerj.br/v22n4/v22n4a12.pdf

11. Universidade do Estado do Pará. Conselho Universitário. Resolução no 2.808/15 - CONSUN, 18 de março de 2015; 2015.15 p. Fixa normas complementares para execução do programa de monitoria no âmbito da Universidade do Estado do Pará.

12. Universidade do Estado do Pará. Centro de Ciências Biológicas e da Saúde. Escola de Enfermagem Magalhães Barata. Projeto pedagógico do Curso de Graduação em Enfermagem. Belém, PA; 2013. 118 p. Aprovado pela Resolução n 2.666/13 - CONSUN, de 25 de fevereiro de 2014.

13. Teixeira E. As três metodologias: acadêmica, da ciência e da pesquisa. 8a ed. Petrópolis, RJ: Vozes; 2011. 203 p.

14. Bardin L. Análise de conteúdo. São Paulo (SP): Edições 70; 2011. 279 p.

15. Freire P. Pedagogia da autonomia: saberes necessários à prática educativa. 54a ed. Rio de Janeiro (RJ): Paz e Terra; 2016.143 p.

16. Freire P. Pedagogia do oprimido. 63a ed. Rio de Janeiro (RJ), São Paulo (SP): Paz e Terra; 2017. 253 p.

17. Freitas DA, Santos EMS, Lima LVS, Miranda LN, Vasconcelos EL, Nagliate PC. Saberes docentes sobre processo ensino-aprendizagem e sua importância para a formação profissional em saúde. Interface [Internet]. 2016[cited 2016 Aug 16];20(57):437-48. Available from: http://www.scielo.br/pdf/icse/2016nahead/1807-5762-icse-1807-576220141177.pdf

18. Masetto MT. Competência pedagógica do professor universitário. 3ª ed. São Paulo (SP): Summus; 2015.207 p.

19. Melo LA, Bezerra MVM, Melo LA, Martins CMA, Correia MS, Albuquerque RS. Diálogo sobre a construção de um mapa conceitual como recurso para aprendizagem: relato de experiência. Rev Iberoamericana Educ Investig Enferm[Internet]. 2015 [cited 2017 Apr 20];5(4):50-8. Available from: http://www.enfermeria21.com/revistas/aladefe/articulo/184/

20. Matoso LML. A importância da monitoria na formação acadêmica do monitor: um relato de experiência. Rev Científ Esc Saúde Univ Potiguar [Internet]. 2014[cited 2017 Jul 05];3(2):77-83. Available from: https://repositorio.unp.br/index.php/catussaba/article/view/567/461

21. Moraes GNB, Falcão JGB, Sandes AAG, Rodrigues BR, Nascimento IYM, Shiosaki RK, et al. Vivência na monitoria de anatomia humana: relato de experiência de discentes-monitores do curso de fisioterapia. Rev Travessias [Internet]. 2016 [cited 2017 Jul 05];10(3):67-79. Available from: http://e-revista.unioeste.br/index.php/travessias/article/view/14863/10236

22. Natário EG, Santos AAA. Programa de monitores para o ensino superior. Estud Psicol (Campinas) [Internet]. 2010 [cited 2017 Jul 05];27(3):355-64. Available from: http://www.scielo.br/pdf/estpsi/v27n3/07.pdf

23. Nascimento FB, Barletta JB. O olhar do docente sobre a monitoria como instrumento de preparação para a função de professor. Rev Cereus[Internet]. 2011[cited 2016 Feb 11];(5):12 p. Available from: http://www.ojs.unirg.edu.br/index.php/1/article/download/57/75

24. Ponte KP, Holanda MTS, Andrade AGS. Contribuições do programa de monitoria para a formação acadêmica e iniciação à docência: uma reflexão a partir do referencial histórico-cultural. Cad Grad [Internet]. Faculdade Luciano Feijão. 2015[cited 2017 Jul 05];2(3):1-17. Available from: http://flucianofeijao.com.br/novo/wp-content/uploads/2016/03/CONTRIBUICOES DO PROGRAMA_DE_MONITORIA.pdf

25. Souza FMS, Barboza LC. A prática de monitoria no ensino de psicologia: ciência e profissão. Interbio [Internet]. 2014 [cited 2017 Jul 05];8(1):17-23. Available from: http://www.unigran.br/interbio/paginas/ed_anteriores/vol8_num1/arquivos/artigo2.pdf

26. Andrade SR, Piccoli T, Ruoff AB, Ribeiro JC, Sousa FM. Normative grounds of health care practice in Brazilian nursing. Rev Bras Enferm [Internet]. 2016 [cited 2017 May 01];69(6):1020-8. Available from: http://www.scielo.br/pdf/reben/v69n6/en 0034-7167reben-69-06-1082.pdf

27. Backes DS, Backes MS, Erdmann AL, Büscher A. O papel profissional do enfermeiro no Sistema Único de Saúde: da saúde comunitária à Estratégia de Saúde da Família. Ciênc Saúde Colet[Internet]. 2012 [cited 2016 Jul 13];17(1):223-30. Available from: http://www.scielo.br/pdf/csc/v17n1/a24v17n1.pdf

28. Presotto GV, Ferreira MBG, Contim D, Simões ALA. Dimensions of the work of the nurse in the hospital setting. Rev RENE [Internet]. 2014[cited 2016 Jul 13];15(5):760-70. Available from: http://www.periodicos.ufc.br/rene/article/download/3238/2493

29. Sanna MC. Os processos de trabalho em enfermagem. Rev Bras Enferm [Internet]. 2007 [cited 2016 Jul 13];60(2):221-4. Available from: http://www.scielo.br/pdf/reben/v60n2/a17v60n2.pdf

30. Brasil. Conselho Nacional de Educação. Câmara de Educação Superior. Resolução CNE/CES no 3, de 7 de novembro de 2001. Institui Diretrizes Curriculares Nacionais do Curso de Graduação em Enfermagem. [Internet]. 2001[cited 2016 Mar 29]. 6 p. Available from: http://portal.mec.gov.br/cne/arquivos/pdf/CES03.pdf

31. Lima CC, Guzman SM, Benedetto MAC, Gallian DMC. Humanities and humanization in healthcare: the literature as a humanizing element for health science undergraduates. Interface [Internet]. 2014[cited 2016 Mar 29];18(48):139-50. Available from: http:// www.scielo.br/pdf/icse/v18n48/en_1807-5762-icse-18-48-0139.pdf

32. Winters JRF, Prado ML. Processo de formação crítico-criativo: percepção dos formandos de enfermagem. Rev lberoamericana Educ Investig Enferm [Internet]. 2015 [cited 2017 Apr 20];5(2):17-24. Available from: http://www.enfermeria21.com/revistas/aladefe/ articulo/160/ 